\title{
How Sociodemographic Variables and Social Values Predict Work-Related General Anxiety in Brunei Public and Private Sector Employees
}

\author{
Lawrence Mundia \\ ORCID ID 0000-0003-1494-2923 \\ Psychological Studies and Human Development Academic Group \\ Sultan Hassanal Bolkiah Institute of Education, Universiti Brunei Darussalam \\ Jalan Tungku Link, Gadong BE 1410, Bandar Seri Begawan, Brunei Darussalam \\ Tel: 6-738-939-465 E-mail: lawrence.mundia@ubd.edu.bn
}

Received: November 8, 2019 Accepted: December 5, 2019 Published: December 23, 2019

doi:10.5296/iss.v7i2.16117ＵRL: http://dx.doi.org/10.5296/iss.v7i2.16117

\begin{abstract}
Background: Numerous studies show that employees tend to have anxiety and other psychological problems at places of work. The present investigation explored the prevalence of work-related general anxiety in 860 randomly chosen Brunei public and private sector employees.

Methods: A quantitative field survey design was used to reach many participants and employed binary logistic regression procedure with backward elimination in analyzing the data.

Results: Males were far less likely to have work-related general anxiety compared to females. Employees who sought help from prayer / religion were nearly 1.7 times more likely to have work-related general anxiety compared to those who do not get such help. Workers who regularly got help from family members on problems had also high likelihood of possessing a great amount of work-related general anxiety compared to those who did not often get help from family members. Employees with a low educational background had high odds ratios for possessing work-related general anxiety compared to those with high education.

Compared to high scorers: (1) low scorers on peace and security variable were less likely to have work-related general anxiety; (2) low scorers on personal wellbeing and happiness were also less likely to experience work-related general anxiety; (3) low scorers on self-regulation and self-direction were as well less likely to have work-related general anxiety; and (4) low
\end{abstract}




\section{Macrothink}

scorers on employer-employee relationships were equally less likely to have work-related general anxiety issues. However, (5) low scorers on moral obligations were 1.6 times more likely to have work-related general anxiety problems; (6) low scorers on satisfaction with work-related achievements were 1.9 times more likely to have work-related general anxiety; (7) low scorers on interpersonal trust variable had high odds ratios for having work-related general anxiety problems; and (8) low scorers on work stress problems were surprisingly also highly likely to have work-related general anxiety problems.

Conclusions: Sociodemographic variables and social work values presented above had different effects on work-related anxiety in employees. These are the variables to which attention and priority should be directed and accorded when counselling workers.

Keywords: Sociodemographic variables, Social values, Work-related general anxiety, Public and private sector employees, Brunei 


\section{Introduction}

Anxiety is one of the characteristics of neuroticism (Schultz \& Schultz, 1998). According to Raveendran (2017), neuroticism has a significant negative impact on work stress. In addition, Watson and Pennebaker (1989) also found that neuroticism had a direct relationship with job stress. This was supported by Deary and Blenkin (1996) who stated that job stress was a product of personality traits such as neuroticism. Furthermore, Birch and Kamali (2001) found that neuroticism was positively correlated with both job stress and depression. Henderson and Thompson (2007) view anxiety as an automatic defense mechanism to a critical and stressful situation. Moreover, Goyzman (2010) found that individuals who were low in 'internal locus of control' (the externals), tended to experience higher levels of anxiety than those who were high in 'internal locus of control' (the internals). Other researchers also found that external locus of control was positively related with work stress (Jha \& Bano, 2012; Sahraian \& Omdivar, 2014). Overall, anxiety, stress and depression were positively correlated (Bouteyre et al., 2007; Dwamena, 2012). In their work anxiety interview study, Linden and Muschalla (2007) found that both genders exhibited anxiety with females showing more symptoms than males. According to Waghorn et al. (2014) and Ladderud (2017), individuals who suffered from depression and anxiety problems avoided going to a workplace more often than those who had no depression and anxiety. Workplace phobia was first coined by Haines et al. (2002) and defined as a form of anxiety exerted by an individual with a psychological and behavior disturbance as a result of attending a workplace. The three related mental health constructs (depression, anxiety, and stress) can be assessed in a variety of ways including using observations, interviews and questionnaires. One well researched instrument that measures anxiety and its correlates, but was not used in the current study, is the Depression, Anxiety and Stress Scale, DASS (Lovibond \& Lovibond, 1995).

\subsection{Rationale and Justification for the Present Study}

Like elsewhere in the world, Brunei employees in both the public and private sectors face many problems and challenges that deserve to be investigated empirically. Apart from the Employee Satisfaction Index study (Department of Planning, Development and Research, 2014), which looked into government workers' satisfaction, problems related to workplace anxiety have not been probed before. The present study was an attempt to narrow the knowledge gap on this issue. Past research of a psychological nature had addressed a number of problems such as various disabilities (Bradshaw \& Mundia, 2005; Bradshaw \& Mundia, 2006; Tait \& Mundia, 2012a, b; Haq \& Mundia, 2012; Mundia, 2006; Yusuf \& Mundia, 2014; Tait \& Mundia, 2014; Tait, Mundia, \& Fung, 2014; Tait, Mundia, Fung, \& Wong, 2014). Besides disability, previous research also examined the mental health concerns of students in the education system (Mundia 2010a; Mundia, 2010b; Mundia 2012a, b; Mundia, 2013; Mundia, 2015). Most of the teaching and learning research on Brunei has focused on a wide range of school subjects including mathematics and Japanese language (Mundia, 1998; Mundia, 2010c; Mundia, 2010d; Mundia, 2007; Mundia, 2009; Mundia, 2011a; Mundia, 2012c; Keaney \& Mundia, 2014; Mundia \& Metussin, 2019). The training of teachers was also accorded priority by research (e.g. Mundia, 2012d, e; Tait \& Mundia, 2012b; Tait \& Mundia, 2014). Problems associated with conducting research using Brunei student samples were 
investigated by two studies (see Mundia \& Bakar, 2010; Mundia, 2011b). Issues related to common methods bias in research using Brunei samples were reported in two studies (Mundia, 2019a; Mundia, 2019b).

\subsection{Role of Social Values in a Workplace}

There are many ways in which values can be defined or described. Values form an important part of the culture of any society. They provide the general guidelines for normative behaviors. Values such as fundamental rights, patriotism, human dignity, rationality, sacrifice, individuality, equality, and democracy guide our behavior in many ways. Based on our literature sources, values are both "desirable" and "desired" behaviors expected of people in a given group, community or society (Braithwaite \& Scott, 1991). In this definition, the terms "desirable" and "desired" refer to what one "ought" to do and what one "wants" to do respectively (Braithwaite \& Scott, 1991). The use of words "desirable" and "desired" make it difficult to define values precisely. For instance, behaviors that are considered to be desirable or desired in one culture and circumstance may not be viewed the same way in another culture or situation. In addition, values are multi-dimensional and multi-faceted constructs that overlap in some cases (e.g.moral values are somewhat similar to ethical values). Furthermore, values may be classified in a variety of ways. For example, we have the so-called personal values (e.g. an individualistic preference for high academic achievement), national values (e.g. American values), regional values (e.g. western values), work values (e.g. what we prefere to do and experience at the place of work), and collectivist values (e.g. communal ways of living). Attempts have also been made by researchers to identify the most common values referred to as world-wide universal values or cross-cultural values (Triandis et al., 1972).

The present study refers to values as "social values" because they are embedded in several social domains such as cultural, family, religious, moral, ethical, political, educational, occupational, and sociological disciplines (Braithwaite \& Scott, 1991). At the time of conducting the current study, there was a dearth and scarcity of research on social values. However, Inglehart's $(1971 ; 1977)$ works addressed the issues of social values. Inglehart $(1971 ; 1977)$ focused on two types of social values, namely: materialist values that were a response to the need for economic and physical security (e.g. fighting rising prices); and nonmaterialist values that were concerned with social and self-actualizing needs (e.g. decentralizing government decision-making processes). On social values related to employees, Hofstede (1980) discussed four types of work values: power distance (e.g. social inequality and unequal power balance); uncertainty avoidance (e.g. ways of dealing with the unknown future); individualism (autonomy) versus collectivism (group interdependence); and masculinity (e.g. male assertiveness) versus femininity (e.g. female nurturance). Hofstede (1980) argued that these four basic work values which he operationalized at the ecological level could be modified for use in non-work contexts. Much of the social psychology and sociological research on social values and work values has tended to focus on measuring the concerns people have for the self and others, known as social value orientation, SVO (van Lange, 1999; Murphy et al., 2011). Under the SVO theory, people are divided into four social values based categories. People who emphasize benefitting at the expense of others are 
referred to as individualistic or egoistic. Those who seek to exploit gains from individual differences are said to be competitive (competitors or proselfs). Individuals who advocate equality or collective interest (also known as joint / equal outcomes) are known as cooperatives (cooperators or prosocials). Persons with narrow self-interest but much compassion for others are labelled as altruistic. Like the interpersonal trust concept, there are also many questionnaires that measure both social and work values described by Robinson et al. (1991). The present study only used some items from the Rokeach's Value Survey (Rokeach, 1967) and the Goal and Mode Values Inventories (Braithwaite \& Law, 1985). Rokeach (1967) divided the values into two categories: terminal values (which referred to goals in life); and instrumental values (by which he meant modes of conduct). The Goal and Mode Values Inventories (Braithwaite \& Law, 1985) were an attempt to improve on Rokeach's (1967) Value Survey instrument. Braithwaite and Law (1985) separated social goals / values from personal goals / values and produced a 3-parts instrument with 13 dimensions: traditional religiosity; personal growth and inner harmony; physical well-being; secure and satisfying interpersonal relationships; social standing; social stimulation; positive orientaion to others; propriety in dress and manners; religious commitment; assertiveness; getting ahead; international harmony; and national strength and order. Besides these instruments, our study also adapted and incorporated some items from the World Values Survey [28] which taps a wider diversity of values including the universal, national, political, security, and moral ones than is measured by the Value Survey (Rokeach, 1967) and the Goal and Mode Values Inventories (Braithwaite \& Law, 1985).

\subsection{Objectives of the Study}

The two main goals of the present study were to:

(a) Assess the relationship between selected sociodemographic variables and work-related anxiety in Brunei public and private sector employees.

(b) Evaluate the relationship between selected social values and work-related anxiety in Brunei public and private sector employees.

\section{Method}

The design, participants, instruments, data analysis techniques, and procedures used in this study are briefly explained separately below.

\subsection{Design}

The quantitative field survey was chosen and used as this strategy could handle a large sample to collect the required data within a short time. Other types of survey research (e.g. postal, online, telephone, and longitudinal) could not do this.

\subsection{Participants}

Brunei had 189,500 public sector employees in 2014 (108,500 or 57.3\% males and 81,000 or $42.7 \%$ females) (Department of Economic Planning and Development. (2015). Of these, $137,300(72.5 \%)$ were full Brunei citizens and permanent residents while 52,200 (27.5\%) 
were foreigners. The total number of private sector employees was not known at the time of collecting data for the present study. Often, the sample size is determined by formulae such as those employed in previous investigations (Yamane, 1967; Chand et al., 2012). For the current study, an appropriate table of population values and corresponding sample sizes developed by Krejcie and Morgan (1970) was used. Using the simple random sampling technique, 822 participants (instead of 384) were recruited from the public sector. However, only 38 persons were recruited from the private sector due to problems in obtaining volunteers to participate in the study. In view of this, the composite sample was 860 from both sectors. The following 5-point inclusion / exclusion criteria were used when recruiting participants for the study: (1) persons of all genders, ethnicities and religions were acceptable; (2) full Brunei citizens and permanent residents; (3) employed in the public and private sectors; (4) willing to volunteer participation in the study; and (5) persons whose individual protocols were not heavily contaminated by common methods bias such as missing values (non-response bias), central tendency error, and extremity response bias. The demographic composition and personal characteristics of the selected participants are presented in

Table 1. Participants' demographic information $(\mathrm{N}=860)$

\begin{tabular}{|c|c|c|c|}
\hline Variable & Gender & Number $(\%)$ & Mean (SD) \\
\hline \multirow[t]{3}{*}{ Age } & All & $860(100 \%)$ & $37.690(9.045)$ \\
\hline & Females & $613(71.300 \%)$ & $37.690(9.262)$ \\
\hline & Males & $247(28.700 \%)$ & $37.710(8.516)$ \\
\hline \multirow[t]{5}{*}{ Race } & Group & Frequency & Percentage \\
\hline & Malay & 810 & 94.200 \\
\hline & Chines & 25 & 2.900 \\
\hline & Others & 22 & 2.600 \\
\hline & Missing & 1 & 0.300 \\
\hline \multirow[t]{4}{*}{ Religion } & Muslim & 837 & 97.300 \\
\hline & Non-Muslim & 12 & 1.400 \\
\hline & No religion & 10 & 1.200 \\
\hline & Missing & 1 & 0.300 \\
\hline \multirow[t]{3}{*}{ Citizenship } & Brunei citizen & 831 & 96.600 \\
\hline & Permanent resident & 26 & 3.000 \\
\hline & Missing & 3 & 0.400 \\
\hline \multirow[t]{5}{*}{ Education } & Low (Primary to Year 13) & 362 & 42.100 \\
\hline & Middle (Post-secondary to diploma) & 194 & 22.600 \\
\hline & High (Bachelor's degree to doctoral & 301 & 35.000 \\
\hline & degree) & 3 & 0.300 \\
\hline & Missing & & \\
\hline \multirow[t]{2}{*}{ Employer } & Public sector (government) & 822 & 95.600 \\
\hline & Private sector (non-government) & 38 & 4.400 \\
\hline
\end{tabular}




\begin{tabular}{|c|c|c|c|}
\hline \multirow[t]{3}{*}{ Marital status } & Single (never married) & 221 & 25.700 \\
\hline & Married & 615 & 71.500 \\
\hline & Divorced (17)/widowed (7) & 24 & 2.800 \\
\hline \multirow{3}{*}{$\begin{array}{l}\text { Do you have } \\
\text { children? }\end{array}$} & Yes & 571 & 66.400 \\
\hline & No & 286 & 33.300 \\
\hline & Missing & 3 & 0.300 \\
\hline \multirow[t]{5}{*}{ District } & Brunei-Muara & 721 & 83.800 \\
\hline & Tutong & 104 & 12.100 \\
\hline & Kuala Belait & 20 & 2.300 \\
\hline & Temburong & 10 & 1.200 \\
\hline & Missing & 5 & 0.600 \\
\hline \multirow{6}{*}{$\begin{array}{l}\text { Who do you live } \\
\text { with }\end{array}$} & Alone & 27 & 3.100 \\
\hline & Parents & 296 & 34.400 \\
\hline & In-laws & 57 & 6.600 \\
\hline & Family members (siblings) & 73 & 8.500 \\
\hline & Spouse and children & 384 & 44.700 \\
\hline & Missing & 23 & 2.700 \\
\hline \multirow{3}{*}{$\begin{array}{l}\text { Do you stay/live in } \\
\text { your own house }\end{array}$} & Yes & 502 & 58.400 \\
\hline & No & 356 & 41.400 \\
\hline & Missing & 2 & 0.200 \\
\hline \multirow{3}{*}{$\begin{array}{l}\text { Are you the chief } \\
\text { wage earner in } \\
\text { your household? }\end{array}$} & Yes & 282 & 32.800 \\
\hline & No & 561 & 65.200 \\
\hline & Missing & 17 & 2.000 \\
\hline
\end{tabular}

\subsection{Intsruments}

Besides the 16-item demographic questionnaire (Part A) which collected the participants' personal data reported in Table 1, we also used 13 scales (Parts B-G of the instrument) that measured a wide range of social values shown in Table 2. The items in Sections B-G were derived from five main sources: (1) items adapted from the Interpersonal Trust Scale (Rotter, 1967), the Value Survey (Rokeach, 1967) and the Goal and Mode Values Inventories (Braithwaite \& Law, 1985); (2); modified items from the World Values Survey (The Social Research Centre \& Australian National University, 2012) which is available online for free download; and (3) the researcher's own constructed items based on the content review of the relevant literature as well as the researcher's conceptualisation of social values in the Brunei context.

Part B consisted of 101 items pertaining to desirable behavioral values in Brunei context that 
made up four subscales shown in Table 2. The items in Part B instruments were rated on 5-point Likert scales (1 Not at all important; 2 Somewhat important; 3 Moderately important; 4 Quite important; 5 Extremely important). One sample instruction and item are provided here to illustrate this section. Rate the following statement according to how you regard it as desirable in your life (To have true friends: 12345 ).

Part $\mathrm{C}$ comprised of 30 items related to preferred basic values in Brunei that were divided into three subscales presented in Table 2. The items in Part $\mathrm{C}$ questionnaires were also rated on 5-point Likert scales (1 Completely unimportant; 2 Not important; 3 . Not very important; 4. More or less important; 5 Important). An example instruction and item from this section is as follows: rate this statement according to the way you believe you ought to behave (To obtain social support or help when you have a problem - 12345 ).

Part D had one 10-item questionnaire that measured the level of interpersonal trust. The items in this instrument were rated on 5-point semantic differential scales (e.g. Rate your trust of people you work with: To what extent do you trust your co-workers (supervisor or boss)? Do not trust at all $1 \quad 2 \quad 3 \quad 3 \quad 4 \quad 5$ Trust completely).

Part E had one 7-item questionnaire that measured work-related general anxiety or worries. The items in this instrument were also rated on 5-point semantic differential scales (e.g. To what degree are you worried about losing your job? - Not at all $1 \quad 2 \quad 3 \quad 4 \quad 4 \quad 5$ Very much).

Part F contained 28 items that formed four questionnaires measuring employees' workplace problems. All the items in this section were rated on 5-point Likert scales (e.g. Please rate the frequency of the following problems you face or are facing at work: Conflicts and not getting along with co-workers (supervisor or boss) - 1 Never; 2 Rare; 3 Sometimes; 4 Often; 5 Always).

The scales in Sections B-G of the instrument were subjected to exploratory factor analysis (EFA). Table 2 shows the domains, factors with their scale names, number of items in each scale, and scale descriptive statistics together with information on scale reliability and validity. Items in each scale were reasonably homogeneous or unidimensional as indicated by the high adjusted or nonspurious item-total correlations. In addition, each scale or subscale had good internal consistency reliability as shown by the high Cronbach alpha coefficients. Furthermore, the domains and their scaels or subscales had adequate construct validity revealed in Table 2 by the percentage (\%) of variance accounted for. Moreover, the Kaiser-Meyer-Olkin measures of sampling adequacy (KMO) and Bartlett's tests of sphericity (BTS) showed that the factor analyses performed were satisfactory and suited the data respectively. 


\section{Macrothink}

Issues in Social Science

ISSN 2329-521X 2019, Vol. 7, No. 2

Table 2. Scale statistics, alpha reliability and construct validity $(\mathrm{N}=860)$

\begin{tabular}{|c|c|c|c|c|c|c|c|c|c|c|c|}
\hline $\begin{array}{l}\mathrm{EFA}^{\mathrm{a}} \text { Factor/Scale } \\
\text { Name }\end{array}$ & Items & Mean & $\mathrm{SEm}^{\mathrm{b}}$ & $\mathrm{SD}^{\mathrm{c}}$ & Median & $\begin{array}{l}\text { Average } \\
\text { CITSr }^{d}\end{array}$ & $\begin{array}{l}\text { Cronbach } \\
\text { Alpha }\end{array}$ & $\begin{array}{l}\% \\
\text { Variance } \\
\text { Accounted }\end{array}$ & $\mathrm{KMO}^{\mathrm{e}}$ & $\begin{array}{l}\mathrm{BTS}^{\mathrm{f}} \\
\mathrm{X}^{2}\end{array}$ & Sig. \\
\hline $\begin{array}{l}\text { Desired behavioral } \\
\text { values }\end{array}$ & 101 & & & & & & & & & & \\
\hline $\begin{array}{l}\text { Factor } 1 \text { - Peace } \\
\text { and security }\end{array}$ & 36 & 157.460 & 0.791 & 23.191 & 163.000 & 0.759 & 0.972 & 24.082 & 0.979 & 57237.2725050 & 0.000 \\
\hline $\begin{array}{l}\text { Factor } 2 \text { - Social } \\
\text { welfare/cultural } \\
\text { duties }\end{array}$ & 26 & 114.150 & 0.524 & 15.362 & 117.000 & 0.783 & 0.958 & 17.642 & & & \\
\hline $\begin{array}{l}\text { Factor } 3 \text { - Personal } \\
\text { wellbeing and } \\
\text { happiness }\end{array}$ & 17 & $59 . .350$ & 0.390 & 11.445 & 60.000 & 0.744 & 0.903 & 12.006 & & & \\
\hline $\begin{array}{l}\text { Factor } 4 \text { - Moral } \\
\text { obligations }\end{array}$ & 11 & 41.960 & 0.255 & 7.478 & 43.000 & 0.682 & 0.861 & 9.779 & & & \\
\hline Total variance & - & - & - & - & - & - & - & 63.509 & & & \\
\hline $\begin{array}{l}\text { Preferred basic } \\
\text { values }\end{array}$ & 30 & & & & & & & & & & \\
\hline $\begin{array}{l}\text { Factor } 1- \\
\text { Self-regulation and } \\
\text { self-direction }\end{array}$ & 17 & 70.180 & 0.358 & 10.485 & 72.000 & 0.638 & 0.948 & 31.492 & 0.958 & 14744.970435 & 0.000 \\
\hline $\begin{array}{l}\text { Factor } 2 \text { - } \\
\text { Self-presentation }\end{array}$ & 7 & 24.240 & 0.155 & 4.555 & 25.000 & 0.609 & 0.853 & 19.715 & & & \\
\hline $\begin{array}{l}\text { Factor } 3 \text { - } \\
\text { Satisfaction with } \\
\text { work-related } \\
\text { achievements }\end{array}$ & 4 & 11.580 & 0.106 & 3.118 & 12.000 & 0.565 & 0.779 & 11.451 & & & \\
\hline $\begin{array}{l}\text { Total variance } \\
\text { Level of } \\
\text { interpersonal trust }\end{array}$ & $\begin{array}{l}- \\
10\end{array}$ & - & - & - & - & - & - & 62.658 & & & \\
\hline $\begin{array}{l}\text { Factor } 1 \text { - Level of } \\
\text { interpersonal trust } \\
\text { General } \\
\text { worries/anxiety }\end{array}$ & $\begin{array}{l}10 \\
7\end{array}$ & 31.700 & 0.237 & 6.956 & 32.000 & 0.703 & 0.911 & 67.234 & 0.859 & $3829.011 \quad 45$ & 0.000 \\
\hline $\begin{array}{l}\text { Factor } 1 \text { - Level of } \\
\text { general anxiety }\end{array}$ & 7 & 38.647 & 0.138 & 6.217 & 33.000 & 0.636 & 0.873 & 66.201 & 0.918 & $3670.046 \quad 21$ & 0.000 \\
\hline $\begin{array}{l}\text { Employees' } \\
\text { workplace } \\
\text { problems }\end{array}$ & 28 & & & & & & & & & & \\
\hline $\begin{array}{l}\text { Factor } 1- \\
\text { Interpersonal } \\
\text { communication } \\
\text { problems }\end{array}$ & 11 & 38.440 & 0.297 & 8.716 & 40.000 & 0.649 & 0.880 & 22.860 & 0.940 & 15683.138378 & 0.000 \\
\hline $\begin{array}{l}\text { Factor } 2- \\
\text { Employer-employee } \\
\text { relationship } \\
\text { problems }\end{array}$ & 8 & 17.820 & 0.164 & 4.811 & 18.000 & 0.667 & 0.920 & 17.249 & & & \\
\hline
\end{tabular}


Factor 3 - Work

5

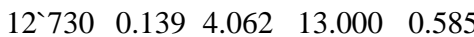

0.865

13.107

stress problems

$\begin{array}{lllllllll}\text { Factor } 4 \text {-Work } & 4 & 13.310 & 0.132 & 3.882 & 14.000 & 0.611 & 0.825 & 10.892\end{array}$

attendance

problems

Total variance

64.107

${ }^{\mathrm{a}} \mathrm{EFA}=$ Exploratory factor analysis; ${ }^{\mathrm{b}} \mathrm{SEm}=$ Standard error of the mean; ${ }^{\mathrm{c}} \mathrm{SD}=$ Standard deviation; ${ }^{\mathrm{d}} \mathrm{CITSr}=$ Averegae Corrected Item-to-Scale correlation; ${ }^{\mathrm{e}} \mathrm{KMO}=$ Kaiser-Meyer-Olkin measure of sampling adequacy; ${ }^{\mathrm{f}} \mathrm{BTS}=$ Bartlett's test of sphericity.

In addition to construct validity, the researcher also examined the convergence and discriminant validity of the instruments presented in Table 2 by correlating the derived measures. The resulting inter-correlations are displayed in Table 3. In this table, any two paired instruments with an inter-correlation $\geq 0.710$ had more than $50 \%$ common variance (an indication of possessing moderate convergent validity). Conversely, paired scales with an inter-correlation below the criterion value of 0.710 had satisfactory discriminant validity.

Table 3. Interscale correlations as evidence of convergent and divergent validity $(\mathrm{N}=860)$

\begin{tabular}{|c|c|c|c|c|c|c|c|c|c|c|c|c|}
\hline Scale $\dagger$ & & 2 & 3 & 4 & 5 & 6 & 7 & 8 & 9 & 10 & 11 & 12 \\
\hline 1 & 1 & & & & & & & & & & & \\
\hline 2 & $0.792^{* *}$ & 1 & & & & & & & & & & \\
\hline 3 & $0.650^{* *}$ & $0.636^{* *}$ & 1 & & & & & & & & & \\
\hline 4 & $0.754^{* *}$ & $0.735^{* *}$ & $0.735^{* *}$ & 1 & & & & & & & & \\
\hline 5 & $0.726^{* *}$ & $0.636^{* *}$ & $0.521^{* *}$ & $0.584^{* *}$ & 1 & & & & & & & \\
\hline 6 & $0.595^{* *}$ & $0.521^{* *}$ & $0.582^{* *}$ & $0.537^{* *}$ & $0.789^{* * *}$ & 1 & & & & & & \\
\hline 7 & $0.323^{* *}$ & $0.265^{* *}$ & $0.404^{* *}$ & $0.350^{* *}$ & $0.369^{* *}$ & $0.402^{* *}$ & 1 & & & & & \\
\hline 8 & $0.344^{* *}$ & $0.297^{* *}$ & $0.317^{* *}$ & $0.378^{* *}$ & $0.402^{* * *}$ & $0.407^{* *}$ & $0.259^{* *}$ & 1 & & & & \\
\hline 9 & $0.455^{* *}$ & $0.493^{* *}$ & $0.349^{* *}$ & $0.336^{* *}$ & $0.473^{* *}$ & $0.402^{* *}$ & $0.116^{* *}$ & $0.141^{* *}$ & 1 & & & \\
\hline 10 & $0.314^{* * *}$ & $0.276^{* *}$ & $0.189^{* *}$ & $0.211^{* *}$ & $0.416^{* *}$ & $0.393^{* *}$ & $0.104^{* *}$ & $0.277^{* *}$ & $0.271^{* *}$ & 1 & & \\
\hline 11 & $0.265^{* *}$ & $0.235^{* *}$ & $0.177^{* *}$ & $0.167^{* *}$ & $0.375^{* *}$ & $0.355^{* *}$ & $0.104^{* *}$ & $0.291^{* *}$ & $0.261^{* *}$ & $0.771^{* *}$ & 1 & \\
\hline 12 & $0.180^{* *}$ & $0.178^{* *}$ & $0.118^{* *}$ & $0.105^{* *}$ & $0.267^{* *}$ & $0.278^{* *}$ & $0.177^{* *}$ & $0.226^{* *}$ & $0.135^{* *}$ & $0.576^{* *}$ & $0.642^{* * *}$ & 1 \\
\hline 13 & $0.210^{* *}$ & $0.181^{* *}$ & $0.179^{* *}$ & $0.179^{* *}$ & $0.277^{* *}$ & $0.278^{* *}$ & $0.130^{* *}$ & $0.250^{* *}$ & $0.194^{* *}$ & $0.605^{* *}$ & $0.488^{* * *}$ & $0.424^{* * *}$ \\
\hline
\end{tabular}

$\dagger$ Scale - 1: Peace and security; 2: Social welfare / cultural duties; 3: Personal wellbeing and happiness; 4: Moral obligations; 5: Self-regulation and self-direction; 6: Self-presentation; 7: Satisifaction with work-related achievements; 8: Level of interpersonal trust; 9: Level of general anxiety; 10: Interpersonal communication problems; 11: Employer-employee relationships; 12: Work stress problems; 13: Work attendance problems

The meaning of low scores on each scale in the present study is briefly explained below in terms of a comparison between low scorers ( $\leq$ Median value, coded 1 ) versus high scorers ( $\geq$ Median value, coded 0 ). The scale median values are presented in Table 2 . 
- Peace and security - low scores mean that you do not have much peace and security in your mind.

- Social welfare / cultural duties - low scores mean that you tend to behave in socially and culturally unacceptable ways.

- Personal wellbeing and happiness problems - low scores mean that your life is going on well as desired or planned.

- Moral obligations - low scores mean that you sometimes do not know what things are right and wrong and behave accordingly.

- Self-regulation and self-direction problems - low scores mean that you have no problems of controlling and managing your life.

- Self-presentation - low scores mean that you may have low self-confidence and self-esteem and tend to present yourself in a negative manner or direction.

- Satisifaction with work-related achievements - low scores mean that you are dissatisfied with your work achievements.

- Interpersonal trust problems - low scores mean that you distrust others.

- General anxiety problems - low scores mean that you have fewer worries at work.

- Interpersonal communication problems - low scores mean that you have fewer communcation problems.

- Employer-employee relationship problems - low scores mean that you often get along well with employers or bosses.

- Work stress problems - low scores mean that you have fewer stressful problems at work.

- Work attendance problems - low scores mean that you do not have many problems that affect your work attendance.

\subsection{Data Analysis}

All variables (both independent and dependent) were categorical. The data were analyzed using descriptive statistics (frequencies, percentages, mean, and standard deviation) and inferential statistics (Pearson correlations and hierarchical binary logistic regression analysis). All the analyses were performed on SPSS Version 22.

\subsection{Procedures}

The present study was funded by the Brunei Research Council (BRC) in the Government of Brunei Darussalam through the University of Brunei Darussalam (UBD). Written permission and approval to conduct the study were obtained from the University of Brunei Darussalam Ethics Committee. In addition, ethical conditions and rights (e.g. anonymity, confidentiality, privacy, voluntary participation, protection from harm, and informed consent) for 
participating in the study were first explained verbally in either English or Bahasa Melayu language to individual research participants prior to collecting the data. After this, verbal and written informed consent were secured from each research participant in either of the two languages at the time and place of collecting the data. Only persons who voluntarily agreed to participate in the study were recruited. Coercion and deception were not used when recruiting the participants. Furthermore, all the study's research tools were written in simple English language requiring only Grade 7 or Year 7 level of education. To address and reduce any possible linguistic and cultural biases, parallel bilingual items were presented on the instruments in both English and Bahasa Melayu, the main and official language of Brunei spoken by the majority of the people. Above all, data collection occurred in in the participants' work environments to increase the study's ecological validity.

\section{Results}

The major findings of the present study are presented and explained below according to the objectives of the investigation.

\subsection{Relationship between Sociodemographic Variables and Work-Related General Anxiety}

To determine the relationships between sociodemographic variables and work-related general anxiety, Spearman correlation method and the binary logistic regression analysis with backward elimination were used. Spearman correlation was suitable to use since our sociodemographic variables were categorical rather than continuous while the dependent variable, DV (work-related general anxiety) was dichotomous. The binary logistic regression enabled the researcher to explore, identify and select sociodemographic variables that were most relevant to predicting work-related general anxiety. This type of regression analysis required a dichotomous dependent variable (DV) while the independent variables (IVs) could be continuous, dichotomous, multi-categorical, or a combination of these. In the present study, the DV was, as stated above, work-related general anxiety which was dichotomized at the median score (see Table 2). Low scorers were coded one (1) while higher scorers were coded zero (0). Only two sociodemographic variables had appreciable low but significant positive correlations with work-related general anxiety: gender $[\mathrm{r}(860)=0.185, \mathrm{p}<.01]$ and chief wage earner in the family / household $[\mathrm{r}(860)=0.107, \mathrm{p}<.01]$.

The findings of the binary logistic regression analysis are presented in Table 4. In Step 1 (Model 1), all the sociodemographic IVs were entered and regressed on the DV in 14 iterative times using SPSS (Version 22). For the sake of brevity, Table 4 shows only the specific contribution of each categorical IV to work-related general anxiety in the first and last steps. Step 1 (first model) was overfitted and less efficient because it contained both the needed and unwanted IVs. The unnecessary IVs had relatively higher standard errors. The SPSS hierarchically removed the irrelevant terms stepwise in the subsequent models. Though underspecified, Step 14 (last model) contained the best two and statististically significant predictors for work-related general anxiety that had lower standard errors after adjusting for non-desirable variables. The most suitable IVs were: male gender $(\mathrm{n}=235)$ and seeking help from prayer / religion $(n=622)$. The whole binary logistic model accounted for about 7-9\% of the common variance between the IVs and DV in the first step and approximately $5-7 \%$ in 
the last step. The model was also acceptable as illustrated by the nonsignificant $\mathrm{X}^{2}$ fit indices at the bottom of Table 4 .

Compared to females (reference or comparison group coded $0, n=578)$, males $(n=235)$ were far less likely to have work-related general anxiety $(\mathrm{B}=-0.819, \mathrm{p}<.01 ; \mathrm{AOR}=0.441$, 95\% CI $=0.327-0.594$, see Table 4). However, employees who sought help from prayer / religion $(\mathrm{n}=622)$ were nearly 1.7 times more likely to have work-related general anxiety compared to those who did not get such help, $\mathrm{n}=191(\mathrm{~B}=0.505, \mathrm{p}<.01 ; \mathrm{AOR}=1.656,95 \%$ $\mathrm{CI}=1.380-1.988)$. Similarly, workers who regularly got help from family members on problems $(\mathrm{n}=709)$ had also high likelihood of possessing a great amount of work-related general anxiety compared to those who did not often get help from family members, $\mathrm{n}=104$ $(\mathrm{B}=0.400, \mathrm{p}<.05 ; \mathrm{AOR}=1.553,95 \% \mathrm{CI}=1.001-2.411)$. In addition, employees with a low educational background $(\mathrm{n}=333)$ had high odds ratios for possessing work-related general anxiety compared to those with high education, $\mathrm{n}=297(\mathrm{~B}=0.299, \mathrm{p}<.10 ; \mathrm{AOR}=1.348,95 \%$ $\mathrm{CI}=0.962-1.890)$.

Table 4. Detailed relationships between sociodemographic variables and level of general work anxiety from binary logistic regression $(\mathrm{N}=860)$

\begin{tabular}{|c|c|c|c|c|c|c|}
\hline \multirow[b]{2}{*}{ Model $\uparrow /$ Variables } & \multirow[b]{2}{*}{ B } & \multirow[b]{2}{*}{ SE } & \multirow[b]{2}{*}{ Sig. } & \multirow[b]{2}{*}{ OR } & \multicolumn{2}{|c|}{$95 \% \mathrm{CI}$ for $\mathrm{OR}$} \\
\hline & & & & & Lower & Upper \\
\hline \multicolumn{7}{|l|}{ Step 1} \\
\hline Males $(\operatorname{coded} 1, \mathrm{n}=235)$ & -0.717 & 0.194 & $0.000 * *$ & 0.488 & 0.334 & 0.713 \\
\hline Private employer $(\operatorname{coded} 1, \mathrm{n}=35)$ & 0.052 & 0.363 & 0.887 & 1.053 & 0.517 & 2.143 \\
\hline Educational level & & & 0.218 & & & \\
\hline Low education ${ }^{\mathrm{a}}(\operatorname{coded} 1, \mathrm{n}=333)$ & 0.299 & 0.172 & 0.083 & 1.348 & 0.962 & 1.890 \\
\hline Middle education ${ }^{\mathrm{b}}(\operatorname{coded} 2, \mathrm{n}=183)$ & 0.108 & 0.195 & 0.579 & 1.114 & 0.761 & 1.632 \\
\hline $\begin{array}{l}\text { Sought help from counsellors (Yes, coded } 1 \text {, } \\
n=64)\end{array}$ & -0.076 & 0.281 & 0.787 & 0.927 & 0.535 & 1.607 \\
\hline $\begin{array}{l}\text { Sought help from family members (Yes, } \\
\text { coded } 1, \mathrm{n}=709 \text { ) }\end{array}$ & 0.440 & 0.224 & $0.050 *$ & 1.553 & 1.001 & 2.411 \\
\hline $\begin{array}{l}\text { Sought help from prayer/religion (Yes, } \\
\text { coded } 1, \mathrm{n}=622 \text { ) }\end{array}$ & 0.610 & 0.178 & $0.001 * *$ & 1.840 & 1.298 & 2.607 \\
\hline $\begin{array}{l}\text { Sought help from Bomo }{ }^{c} \text { (Yes, coded 1, } n= \\
\text { 8) }\end{array}$ & 0.116 & 0.752 & 0.877 & 1.123 & 0.257 & 4.903 \\
\hline $\begin{array}{l}\text { Sought help from friends (Yes, coded } 1, n= \\
\text { 436) }\end{array}$ & -0.216 & 0.160 & 0.178 & 0.806 & 0.589 & 1.104 \\
\hline $\begin{array}{l}\text { Sought help from online social networking } \\
\text { (Yes, coded } 1, n=436 \text { ) }\end{array}$ & 0.245 & 0.336 & 0.466 & 1.278 & 0.661 & 2.470 \\
\hline $\begin{array}{l}\text { Sought help from a religious person (Yes, } \\
\text { coded } 1, \mathrm{n}=159 \text { ) }\end{array}$ & 0.138 & 0.199 & 0.487 & 1.148 & 0.777 & 1.697 \\
\hline Marital status & & & 0.458 & & & \\
\hline
\end{tabular}


Single $(\operatorname{coded} 1, \mathrm{n}=221)$

Married (coded 2, $\mathrm{n}=615)$

$\begin{array}{ll}-0.234 & 0.455\end{array}$

0.1390 .406

Do you have children? (Yes, coded 1, $\mathrm{n}=$ 550)

Who do you live with?

Live alone (coded 1, $\mathrm{n}=26$ )

Live with parents (coded 2, $\mathrm{n}=286$ )

Live with in-laws (coded $3, \mathrm{n}=57$ )

Live with siblings (coded $4, n=66$ )

District

Brunei-Muara $(\operatorname{coded} 1, \mathrm{n}=682)$

Tutong (coded 2, $\mathrm{n}=103$ )

Kuala Belait (coded 3, $\mathrm{n}=19$ )

$\begin{array}{ll}-0.455 & 0.266\end{array}$

\begin{tabular}{lllllll} 
& \multicolumn{7}{c}{0.830} & & & \\
-0.325 & 0.450 & 0.470 & 0.723 & 0.299 & 1.746 \\
-0.130 & 0.201 & 0.519 & 0.878 & 0.593 & 1.302 \\
0.137 & 0.303 & 0.652 & 1.146 & 0.633 & 2.077 \\
0.081 & 0.295 & 0.785 & 1.084 & 0.608 & 1.932 \\
& & 0.962 & & & \\
-0.236 & 0.469 & 0.614 & 0.789 & 0.315 & 1.981 \\
-0.221 & 0.493 & 0.654 & 0.802 & 0.305 & 2.108 \\
-0.148 & 0.677 & 0.827 & 0.862 & 0.229 & 3.251 \\
-0.133 & 0.183 & 0.469 & 0.876 & 0.611 & 1.254 \\
& & & & & \\
-0.819 & 0.152 & $0.000^{* *}$ & 0.441 & 0.327 & 0.594 \\
0.505 & 0.093 & $0.000^{* *}$ & 1.656 & 1.380 & 1.988
\end{tabular}

1.070

1.930

2.547

$\begin{array}{lll}0.733 & 1.149 & 0.518\end{array}$

Are you the chief wage earner in your household? (Yes, coded 1, $\mathrm{n}=274$ )

Step 14

Males $(\operatorname{coded} 1, \mathrm{n}=235)$

Sought help from prayer/religion (Yes, coded $1, \mathrm{n}=622$ )

Low education $^{\mathrm{a}}=$ Primary school to General Certificate of Education Advanced Level (GCE A-Level) Middle education $^{\mathrm{b}}=$ General Certificate of Education Ordinary Level (GCE O-Level) to Higher National Diploma (HND)

Bomo $^{\mathrm{c}}=$ traditional healer

$* \mathrm{p}<.05$ (two-tailed)

$* * \mathrm{p}<.01$ (two-tailed)

$\dagger$ Step 1: R Squares $=0.068\left(\right.$ Cox \& Snell), 0.091 (Nagelkerke); Hosmer and Lemeshow $X^{2}(\mathrm{df}=8)=$ $8.083, \mathrm{p}=0.425$

$\dagger$ Step 14: R Squares $=0.050\left(\right.$ Cox \& Snell), 0.066 (Nagelkerke); Hosmer and Lemeshow $X^{2}(\mathrm{df}=2)$ $=0.483, \mathrm{p}=0.785$

\subsection{Relationship between Social Values and Work-Related General Anxiety}

To assess the association between social values and level of work-related general anxiety, we again used Spearman correlation and the binary logistic regression analysis procedure with backward elimination. As reported earlier in Table 3, the best four low but significant social value correlates of work-related general anxiety were: social welfare / cultural duties $[\mathrm{r}(860)$ $=0.493, \mathrm{p}<.01]$; self-regulation and self-direction $[\mathrm{r}(860)=0.473, \mathrm{p}<.01]$; peace and security $[\mathrm{r}(860)=0.455, \mathrm{p}<.01]$; self-presentation $[\mathrm{r}(860)=0.402, \mathrm{p}<.01]$.

For the binary logistic regression analysis, all the variables (both IVs and the DV) were bivariate having been dichotomized at the median score (see Table 2). The binary logistic analysis was completed in 5 iterations but only the first and last steps are shown in Table 5. After adjusting for unnecessary terms, the model accounted for about 11-15\% variance in the first step and $11-14 \%$ in the last step (both with acceptable fit indices shown at the bottom of 
Table 5). Eight (8) social values emerged as significant predictors of work-related general anxiety (four negative and four positive).

Low scorers on peace and security variable $(n=426)$ were less likely to have work-related general anxiety compared to high scorers, $\mathrm{n}=434(\mathrm{~B}=-0.528, \mathrm{p}<.01 ; \mathrm{AOR}=0.590,95 \% \mathrm{CI}$ $=0.418-0.833$ ). In the same way, low scorers on personal wellbeing and happiness, $n=422$ were also less likely to experience work-related general anxiety compared to high scorers, $\mathrm{n}=$ $438(\mathrm{~B}=-0.647, \mathrm{p}<.01 ; \mathrm{AOR}=0.524,95 \% \mathrm{CI}=0.378-0.726)$. Likewise, low scorers on self-regulation and self-direction, $\mathrm{n}=396$, were as well significantly less likely to have work-related general anxiety problems compared to high scorers, $n=464(B=-0.610, p<.01$; $\mathrm{AOR}=0.543,95 \% \mathrm{CI}=0.390-0.757)$. Besides the above three variables, low scorers on employer-employee relationships, $\mathrm{n}=338$, were equally less likely to have major work-related general anxiety issues compared to high scorers, $\mathrm{n}=492(\mathrm{~B}=-0.409, \mathrm{p}<.01$; $\mathrm{AOR}=0.664,95 \% \mathrm{CI}=0.488-0.905)$. However, low scorers on moral obligations $(\mathrm{n}=395)$ were 1.6 times more likely to have work-related general anxiety problems compared to high scorers, $\mathrm{n}=465(\mathrm{~B}=0.454, \mathrm{p}<.01 ; \mathrm{AOR}=1.575,95 \% \mathrm{CI}=1.115-2.224)$. In addition, low scorers on satisfaction with work-related achievements $(n=410)$ were also about 1.9 times more likely to have work-related general anxiety compared to high scorers, $n=450$ ( $\mathrm{B}=$ $0.637, \mathrm{p}<.01 ; \mathrm{AOR}=1.890,95 \% \mathrm{CI}=1.423-2.511)$. Furthermore, evidence in Table 5 shows that low scorers on interpersonal trust variable, $n=391$, had reasonably high odds ratios for having work-related general anxiety problems compared to high scorers, $n=469$ ( $B=0.256$, $\mathrm{p}<.10 ; \mathrm{AOR}=1.291,95 \% \mathrm{CI}=0.969-1.721)$. Moreover, low scorers on work stress problems, $n=403$, were surprisingly also highly likely to have work-related general anxiety problems compared to high scorers, $457(\mathrm{~B}=0.661, \mathrm{p}<.01 ; \mathrm{AOR}=1.937,95 \% \mathrm{CI}=$ 1.436-2.612). This finding is difficult to understand and interpret since the present study had no qualitative interview component to probe it. It seems that creating and maintaining a stress-free working environment, in itself, produces tension and anxiety.

Table 5. Deep relationships between social values and level of general work anxiety using binary logistic regression analysis $(\mathrm{N}=860)$

\begin{tabular}{|c|c|c|c|c|c|c|}
\hline \multirow[b]{2}{*}{ Model $\uparrow /$ Variables } & \multirow[b]{2}{*}{$\mathrm{B}^{\mathrm{a}}$} & \multirow[b]{2}{*}{ S.E. } & \multirow[b]{2}{*}{ Sig. } & \multirow[b]{2}{*}{ OR } & \multicolumn{2}{|c|}{$95 \% \mathrm{CI}$ for OR } \\
\hline & & & & & Lower & Upper \\
\hline \multicolumn{7}{|l|}{ Step 1} \\
\hline Peace and security (low scorers, coded $1, \mathrm{n}=426$ ) & -0.469 & 0.186 & $0.012 * *$ & 0.626 & 0.435 & 0.901 \\
\hline $\begin{array}{l}\text { Social welfare / cultural duties (low scorers, coded } 1 \text {, } \\
n=424 \text { ) }\end{array}$ & -0.175 & 0.176 & 0.319 & 0.839 & 0.595 & 1.184 \\
\hline $\begin{array}{l}\text { Personal wellbeing and happiness (low scorers, } \\
\text { coded } 1, n=422 \text { ) }\end{array}$ & -0.583 & 0.176 & $0.001 * *$ & 0.558 & 0.396 & 0.788 \\
\hline Moral obligations (low scorers, coded 1, $\mathrm{n}=395$ ) & 0.483 & 0.181 & $0.008 * *$ & 1.621 & 1.136 & 2.313 \\
\hline $\begin{array}{l}\text { Self-regulation and self-direction (low scorers, coded } \\
1, \mathrm{n}=396 \text { ) }\end{array}$ & -0.513 & 0.182 & $0.005^{* *}$ & 0.598 & 0.419 & 0.855 \\
\hline Self-presentation (low scorers, coded $1, \mathrm{n}=425$ ) & -0.217 & 0.182 & 0.233 & 0.805 & 0.563 & 1.150 \\
\hline $\begin{array}{l}\text { Satisfaction with work-related achievements (low } \\
\text { scorers, coded } 1, n=410 \text { ) }\end{array}$ & 0.658 & 0.148 & $0.000 * *$ & 1.930 & 1.445 & 2.577 \\
\hline
\end{tabular}


Level of interpersonal trust (low scorers, coded $1, \mathrm{n}=$ 391)

$\begin{array}{llllll}0.239 & 0.148 & 0.106 & 1.270 & 0.950 & 1.698\end{array}$

Interpersonal communication problems (low scorers, coded $1, \mathrm{n}=404$ )

$\begin{array}{llllll}0.061 & 0.173 & 0.726 & 1.063 & 0.757 & 1.492\end{array}$

Employer-employee relationship problems (low scorers, coded $1, \mathrm{n}=368$ )

$\begin{array}{llllll}-0.441 & 0.172 & 0.010^{* *} & 0.643 & 0.459 & 0.901\end{array}$

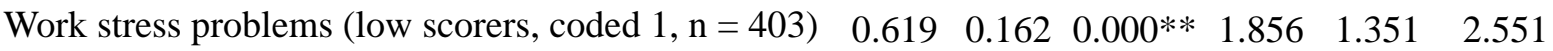

Work attendance problems (low scorers, coded $1, \mathrm{n}=\begin{array}{llllll}0.165 & 0.153 & 0.283 & 1.179 & 0.873 & 1.592\end{array}$ 425)

\section{Step 5}

Peace and security (low scorers, coded $1, \mathrm{n}=426$ )

$\begin{array}{llllll}-0.528 & 0.176 & 0.003 * * & 0.590 & 0.418 & 0.833\end{array}$

Personal wellbeing and happiness (low scorers, coded $1, \mathrm{n}=422$ )

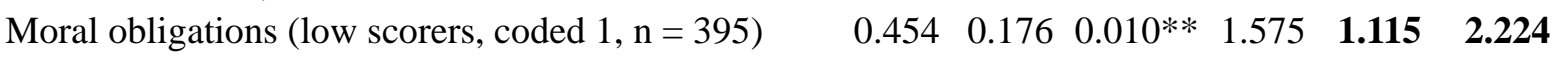

$\begin{array}{llllllll}\text { Self-regulation and self-direction (low scorers, coded } & -0.610 & 0.169 & 0.000 * * & 0.543 & 0.390 & 0.757\end{array}$

$1, \mathrm{n}=396)$

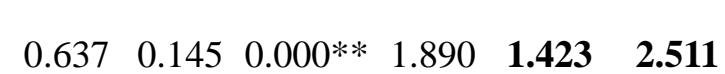

scorers, coded $1, \mathrm{n}=410$ )

Level of interpersonal trust (low scorers, coded $1, \mathrm{n}=$ 391)

$\begin{array}{llllll}0.256 & 0.147 & 0.082 & 1.291 & 0.969 & 1.721\end{array}$

Employer-employee relationship problems (low scorers, coded $1, \mathrm{n}=368$ )

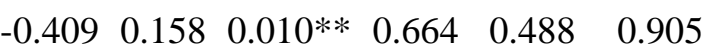

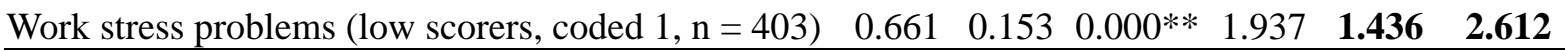

$* * \mathrm{p}<.01$ (two-tailed)

$\dagger$ Step 1: R Squares $=0.111\left(\right.$ Cox \& Snell), 0.149 (Nagelkerke); Hosmer and Lemeshow $X^{2}(\mathrm{df}=8)=$ 21.316, $\mathrm{p}=0.916$

$\dagger$ Step 5: R Squares $=0.107\left(\right.$ Cox \& Snell), 0.143 (Nagelkerke); Hosmer and Lemeshow $X^{2}(\mathrm{df}=8)=$ 27.727, $\mathrm{p}=0.583$

$\mathrm{B}^{\mathrm{a}}$ : the $\mathrm{B}$ and other coefficients in this table refer to the low scorers on all the variables (coded 1) who were compared to the high scorers (reference group coded.

\section{Discussion}

Most of the findings discussed below are not compared to previous trends in Brunei due to lack of similar past research and data based on the same variables as investigated in the current study.

\subsection{Relationship between Sociodemographic Variables and Work-Related General Anxiety}

Briefly discuss below are the implications of the findings on the relationship between sociodemographic variables and work-related general anxiety in Brunei public and private sector employees. Some of the findings are supported by previous research. Males were far less likely to have work-related general anxiety compared to females. In their work anxiety interview study, Linden and Muschalla (2007) found that both genders exhibited anxiety with females showing more symptoms than males. The literature review in the current study indicated that there were more males than females in the Brunei workforce (Department of 


\section{Mll Macrothink}

Economic Planning and Development, 2015). Males do not only outnumber females among Brunei employees, but also constitute the majority of the bosses (ministers, chief executive officers, directors, managers, heads of departments, and supervisors). In view of this, males are in control, make most decisions, and are thus less anxious at places of work.

Employees who sought help from prayer / religion were nearly 1.7 times more likely to have work-related general anxiety compared to those who do not get such help. This finding makes sense since the purpose of religion is to pray to God for divine intervention when someone has big problems that are beyond her / his resources and capacity to solve. Workers who regularly got help from family members (highs in external locus of control) on problems had high likelihood of possessing work-related general anxiety compared to those who did not often get help from family members (highs in internal locus of control). Goyzman (2010) found that individuals who were low in 'internal locus of control' (the externals), tended to experience higher levels of anxiety than those who were high in 'internal locus of control' (the internals). Researchers also found that external locus of control was positively related with work stress (Jha \& Bano, 2012; Sahraian \& Omdivar, 2014).

Employees with a low educational background had high odds ratios for possessing work-related general anxiety compared to those with high education. Workers with a low education experience more anxiety than those with high education for two main reasons. First, they are generally subordinates with less power. Second, being at the bottom of the hierarchy, they do harder and stressful work than counterparts up the ladder and are controlled by more bosses than other categories of workers.

\subsection{Relationship between Social Values and Work-Related General Anxiety}

As explained above, much of the social psychology and sociological research and literature on social values and work values tended to focus on the concerns people have for the self and others, known as social value orientation, SVO (van Lange, 1999; Murphy et al., 2011). However, the four categories in which people are divided under the SVO theory were not reflected in the findings of the current research. In view of this, the researcher has provided his own interpretations of the major findings from the current study regarding the relationship between social values and work-related general anxiety in Brunei public and private sector employees.

Low scorers on peace and security variable were less likely to have work-related general anxiety compared to high scorers. Thus people who care less about their own peace and security would not be expected to care much about their work. In terms of this type of orientation to life, they would naturally experience less work-related general anxiety. Low scorers on personal wellbeing and happiness were less likely to experience work-related general anxiety compared to high scorers. Since these people are not much concerned about their personal wellbeing and happiness, they would not be expected to be very worried with their work and workplace environment. Likewise, low scorers on self-regulation and self-direction were, as well, less likely to have work-related general anxiety problems compared to high scorers. People who have the ability to control and manage their lives effectively are expected to have fewer work-related general anxiety problems. 
Low scorers on employer-employee relationships were equally less likely to have major work-related general anxiety issues compared to high scorers. In the way the relationship scale was scored, workers with fewer relational conflicts with their supervisors were expected to have lower work-related general anxiety problems. Low scorers on moral obligations were 1.6 times more likely to have work-related general anxiety problems compared to high scorers. This finding is true and meaningful. People who behave immorally, tend to have interpersonal relations that are marked with conflicts. If they indulge in such behavior at work, their actions create general anxiety for both the perpetrator and the victim.

Low scorers on satisfaction with work-related achievements were also about 1.9 times more likely to have work-related general anxiety compared to high scorers. Individuals who are dissatisfied with their work achievements could be expected to have work-related general anxiety problems. Low scorers on interpersonal trust variable had reasonably high odds ratios for having work-related general anxiety problems compared to high scorers. This is because they do not trust anyone at work. The mistrust generates work-related general anxiety.

Low scorers on work stress problems were surprisingly also highly likely to have work-related general anxiety problems compared to high scorers. This finding is difficult to understand and interpret since the present study had no qualitative interview component to probe it. It seems that creating and maintaining a stress-free working environment, in itself, produces tension and anxiety. As stated by Schultz and Schultz (Schultz \& Schultz, 1998), anxiety is one of the characteristics of neuroticism. Neuroticism was found to be correlated with work stress by other studies (Raveendran, 2017; Watson and Pennebaker, 1989; Deary \& Blenkin, 1996; Birch \& Kamali, 2001).

\section{Conclusion}

Some sociodemographic variables and social values were found to be related either negatively or positively with work-related general anxiety in the current study. Variables that lead to increased work-related general anxiety were identified by positive associations. It is these variables that need to be targeted and emphasized when counseling affected employees since work anxiety affects productivity adversely, if not treated.

\section{Limitations of the Study}

The present study had two main limitations that need to be addressed by future reseach. First, it did not include an interview component with probes to explore further the participants' responses from the quantitative surveys. Second, the number of participants from the private sector $(\mathrm{n}=38$ ) was too small. Despite these shortcomings, the current study's findings have practical significance that may be relevant to policy-makers and researchers in Brunei and elsewhere.

\section{References}

Birch, D. N, \& Kamali, F. (2001). Psychological stress, anxiety, depression, job satisfaction, and personality characteristics in pre-registration house officers. Postgraduate Medical Journal, 77(904), 109-121. 
Bouteyre, E., Maurel, M., \& Bernand, J.L. (2007). Daily hassles and depressive symptoms among first year psychology students in France: the role of coping and social support. Stress Health, 23, 93-99.

Bradshaw, L., \& Mundia, L. (2005). Understanding preservice teachers' construct of disability: a metacognitive process. Disability and Society, 20(5), 563-574. http://dx.doi.org/10.1080/09687590500156329

Bradshaw, L., \& Mundia, L. (2006). Attitudes to and concerns about inclusive education: Bruneian inservice and preservice teachers. International Journal of Special Education, 21(1), $35-41$.

Braithwaite, V. A., \& Law, H. G. (1985). Testing the adequacy of Rokeach value survey. Journal of Personality and Social Psychology, 49, 250-263.

Braithwaite, V. A., \& Scott, W. A. (1991). Values. In Robinson, J. P., Shaver, P. R., Wrightsman L. S. (Eds.), Measures of personality and social psychological attitudes (Vol. I, pp. 661-753). San Diego, CA: Academic Press.

Chand, M. B., Upadhyay, B. P., \& Maskey, R. (2012). Biogas option for mitigating and adaptation of climate change. Rentech Symposium Compendium, 1, 5-9.

Deary, I., \& Blenkin, H. (1996). Models of job-related stress and personal achievement among consultant doctors. British Journal of Psychology, 87(1), 3-27.

Department of Economic Planning and Development. (2015). Labor force survey 2014: Preliminary report. Bandar Seri Begawan: Prime Minister's Office; 2015.

Department of Planning, Development and Research. (2014). Employee satisfaction index study: Baseline and needs analysis report. Bandar Seri Begawan: Ministry of Education.

Dwamena, M. A. (2012). Stress and its effects on employees productivity; a case study of Ghana ports and habours authority. Commonwealth Executive Master of Business Administration Thesis. Takoradi: Institute of Distance Learning, Kwame Nkrumah University of Science and Technology.

Goyzman, J. (2010). The Influence of Locus of Control and Stress on Performance. The Huron University College Journal of Learning and Motivation, 48(1), 4.

Haines, M. M., Stansfeld, S. A., Head, J., \& Job, R. (2002). Multilevel modelling of aircraft noise on performance tests in schools around Heathrow Airport London. J. Epidemiol. Community Health, 56, 139-144.

Haq, F. S., \& Mundia, L. (2012). Comparison of Brunei pre-service student teachers' attitudes to inclusive education and specific disabilities: Implications for teacher education. Journal of Educational Research, 105(5), 366-374. http://dx.doi.org/10.1080/00220671.2011.627399

Henderson, D. A., \& Thompson, C. L. (2007). Counseling children: International edition. Belmont, CA: Brooks/Cole Cengage Learning. 


\section{Ml Macrothink}

Hofstede, G. (1980). Cultures' consequences: International differences in work-related values. Beverly Hills, CA: Sage.

Inglehart, R. (1971). The silent revolution in Europe: Intergenerational change in post-industrial societies. American Political Science Review, 65, 991-1017.

Inglehart, R. (1977). The silent revolution. Princeton, NJ: Princeton University Press.

Jha, R. K., \& Bano, B. (2012). Impact of Locus of Control on Job Stress: An Empirical Study. International Journal of Decision Making in Supply Chain and Logistics, 3(1), 87-95.

Keaney, M, \& Mundia, L (2014). Foreign language learners' motivation and its effects on their achievement: Implications for effective teaching of students studying Japanese at Universiti Brunei Darussalam. International Education Studies, 7(9), 122. http://dx.doi.org/10.5539/ies.v7n9p122

Krejcie, R. V., \& Morgan, D. W. (1970). Determining sample size for research activities. Educational and Psychological Measurement, 30, 607-610.

Ladderud, S. (2017). Depression and anxiety accommodations in workplace: recommendations for employers. Psychology independent study, Paper 1. Retrieved from http://soundideas.pugetsound.edu/psych_independent_study/1

Linden, M., \& Muschalla, B. (2007). Anxiety disorders and workplace-related anxieties. Journal of Anxiety Disorders, 27, 467-474.

Lovibond, P. F., \& Lovibond, S. H. (1995). The structure of negative emotional states: Comparison of the Depression Anxiety Stress Scale with the Beck Depression and Anxiety Inventories. Behav Res Ther, 33, 335-343.

Mundia, L (2015). The Relationship between Personality and Emotional Intelligence: An Exploratory Case of Brunei Student Teachers. Mediterranean Journal of Social Sciences, $6(6$ S1), 133. http://dx.doi.org/10.5901/mjss.2015.v6n6s1p133

Mundia, L. (2006). Aggressive behavior among Swazi upper primary and junior secondary school students: implications for ongoing educational reforms concerning inclusive education. International Journal of Special Education, 21(3), 58-67.

Mundia, L. (2007). Early childhood education in Swaziland and Brunei Darussalam: goals, achievements and challenges. Early Child Development and Care, 177(2), 151-158. http://dx.doi.org/10.1080/03004430500375885

Mundia, L. (2009). Implementation of inclusive education in Brunei Darussalam: Review of possible implications on school counsellors. Electronic Journal for Inclusive Education, 2(4). Retrieved from http://www.cehs.wright.edu/ prenick/Spring_Summer09_Edition/spr_sum09.html

Mundia, L. (2010a). Prevalence of depression, anxiety and stress in Brunei student teachers. Internet Journal of Mental Health, 6(2). Retrieved from http://www.ispub.com/journal/the_internet_journal_of_mental_health.html 
Mundia, L. (2010b). Brunei trainee teachers' coping strategies for stressful situations. $\begin{array}{lllll}\text { International Journal of Psychological } & \text { Studies, } & \text { 2(1), }\end{array}$ http://dx.doi.org/10.5539/ijps.v2n1p79

Mundia, L. (2010c). Problems in learning mathematics: Comparison of Brunei junior high school students in classes with and without repeaters. Journal of Mathematics Research, 2(3), 150-160. http://dx.doi.org/10.5539/jmr.v2n3p150

Mundia, L. (2010d). Implementation of SPN21 curriculum in Brunei Darussalam: A review of selected implications on school assessment reforms. International Education Studies, 3(2), 119-129. http://dx.doi.org/10.5539/ies.v3n2p119

Mundia, L. (2011a). Effects of psychological distress on academic achievement in Brunei student teachers: Identification challenges and counseling implications. Higher Education Studies, 1(1), 51-63. http://dx.doi.org/10.5539/hes.v1n1p51

Mundia, L. (2011b). Social desirability, non-response bias and reliability in a long self-report measure: Illustrations from the MMPI-2 administered to Brunei student teachers. Educational Psychology: An International Journal of Experimental Educational Psychology, 31(2), 207-224. http://dx.doi.org/10.1080/01443410.2010.545049

Mundia, L. (2012a). The mental health profiles of student teachers: Relevance to teacher education and in identifying potential future teacher problems. The Internet Journal of World Health and Societal Politics, 7(2). http://dx.doi.org/10.5580/2c75.

Mundia, L. (2012b). The role of cognitive behavior therapy in fighting non-adherence to medical advice maintained by fear of drug side-effects in a man with cholesterol, obesity and hypertension problems. The Internet Journal of Health, 13(1). http://dx.doi.org/10.5580/2c41

Mundia, L. (2012c). The Assessment of Mathematics Learning Difficulties in a Primary Grade 4 Child with High Support Needs: Mixed Methods Approach. International Electronic Journal of Elementary Education, 4(2), 347-366.

Mundia, L. (2012d). Assessment of GenNEXT learning outcomes at the University of Brunei Darussalam: A qualitative review of selected opportunities, benefits and challenges in human resource development. Journal of International Education and Leadership, 2(3).

Mundia, L. (2012e). Policy changes in Brunei teacher education: Implications for the selection of trainee teachers. The Education Forum, 76(3), 326-342.

Mundia, L. (2013). Relationship between Mental Health and Teaching: Evidence from Brunei Trainee Teachers. International Journal of Mental Health, 42(2/3), 73-98. http://dx.doi.org/10.2753/IMH0020-7411420205

Mundia, L. (2017). How Brunei trainee teachers cope with distress: Counseling implications. BMC Research Notes, 10, 596. http://dx.doi.org/10.1186/s13104-017-2922-0

Mundia, L. (2019a). Satisfaction with work-related achievements in Brunei public and privatesector employees. Cogent Management \& Business, 6(1). 
https://doi.org/10.1080/23311975.2019.1664191

Mundia, L. (2019b). Interpersonal Trust in Brunei Public and Private Sector Employees. In Farazmand, A. (Ed), Global Encyclopedia of Public Administration, Public Policy, and Governance. https://doi.org/10.1007/978-3-319-31816-5

Mundia, L., \& Bakar, H. (2010). The suitability of the EPQ-R short scale for counseling Brunei student teachers when administered in English and Malay languages. Compare, 40(5), 641-658. http://dx.doi.org/10.1080/03057920903478654

Mundia, L., \& Metussin, H. (2019). Exploring factors that improve mathematics achievement in Brunei. Studies in Educational Evaluation, 60, 214-222. https://doi.org/10.1016/j.stueduc.2018.10.003

Murphy, R. O., Ackermann, K. A., \& Handgraaf, M. J. J. (2011). Measuring Social Value Orientation. Judgment and Decision Making, 6(8), 771-781.

Raveendran, T. (2017). Impact of Big-Five personality on job stress of staff: A case study of regional directorate of health services office, Jaffna. Retrieved from https://www.parliament.lk/uploads/documents/paperspresented/annual_report_university_of_ jaffna_2011_est.pdf

Robinson, J. P., Shaver, P. R., \& Wrightsman, L. S. (1991). Measures of personality and social psychological attitudes (Vol. I). San Diego, CA: Academic Press.

Rokeach, M. (1967). Value survey. Sunnyvale, CA: Halgren Tests.

Rotter, J. B. (1967). A new scale for the measurement of interpersonal trust. Journal of Personality, 35, 651-665.

Sahraian, A., \& Omdivar, B. (2014). Ghanizadeh A, Bazrafshan A. Association of job stress with locus of control in nurses. Shiraz E-Medical Journal, 15(2).

http://dx.doi.org/10.17795/semj20588

Schultz, D. P., \& Schultz, S. E. (1998). Theories of personality (8th ed.). Pacific Grove, CA: Brooks/Cole.

Tait, K., \& Mundia, L. (2012a). Preparing teachers to meet the challenges of inclusive education in Negara Brunei Darussalam. In C. I. Forlin (Ed.), Future directions for inclusive teacher education: An international perspective (pp. 60-69). http://dx.doi.org/10.4324/9780203113585

Tait, K., \& Mundia, L. (2012b). The impact of a child with autism on the Bruneian family system. International Journal of Special Education, 27(3), 1-14.

Tait, K., \& Mundia, L. (2014). A Comparison of Brunei and Hong Kong - SAR Student Teachers' Self-efficacy in Implementing Inclusive Education Practices: Implications for Teacher Education. Asian Social Science, 10(1), 51-60. http://dx.doi.org/10.5539/ass.v10n1p51 


\section{Macrothink}

Issues in Social Science

ISSN 2329-521X 2019, Vol. 7, No. 2

Tait, K., Mundia, L., \& Fung, F. (2014). Raising Young Children with Autism SpectrumDisorders in Hong Kong: The Impact of Cultural Values and Stigma on Chinese Parents' Coping strategies. International Journal of Advances in Social Science and Humanities, 2(1), 07-157.

Tait, K., Mundia, L., Fung, F., \& Wong, C. (2014). The impact of traditional Chinese beliefs, stigma and local school service provision on the coping strategies of parents of children with Autism Spectrum Disorders in Hong Kong. Journal of the International Society for Teacher Education, 18(1), 16-25.

The Social Research Centre \& Australian National University. (2012). World Values Survey. Retrieved from http://politicsir.cass.anu.edu.au/sites/politicsir.anu.edu.au/files/world-values-survey-2012-que stionnaire.pdf

Triandis, H. C., Kilty, K. M., Shanmugam, A. V., Tanak, Y., \& Vassiliou, V. (1972). Cognitive structures and the analysis of values. In Triandis H. C. (Ed.), The analysis of subjective culture (pp. 181-263). New York, NY: Wiley.

van Lange, P. A. M. (1999). The pursuit of joint outcomes and equality in outcomes: An integrative model of social value orientation. Journal of Personality and Social Psychology, 77, 337-349.

Waghorn, G., Saha, S., \& McGrath, J. (2014). Correlates of competitive versus noncompetitive employment among adults with psychotic disorders. Psychiatric Services, 65, 476-482.

Watson, D., \& Pennebaker, J. W. (1989). Health complaints, stress, and distress: Exploring the central role of negative affectivity. Psychological Review, 96(2), 234-54.

Yamane, T. (1967). Elementary sampling theory. Englewood Cliffs, CA: Prentice-Hall.

Yusuf, N. M., \& Mundia, L. (2014). The status of counseling in Brunei prisons: Qualitative exploratory case study. Journal of Sociological Research, 5(1), 24-39. http://dx.doi.org/10.5296/jsr.v5i1.5422

\section{Copyright Disclaimer}

Copyright for this article is retained by the author(s), with first publication rights granted to the journal.

This is an open-access article distributed under the terms and conditions of the Creative Commons Attribution license (http://creativecommons.org/licenses/by/3.0/). 